\title{
Are Green Cities Nice Places to Live? Examining the Link between Urban Sustainability and Quality of Life
}

\author{
DAVID S. BIERI, PHD
}

Volume 1, Fall 2013

DOI: http://dx.doi.org/10.3998/mjs.12333712.0001.006

\section{ABSTRACT}

The growing importance of nonmarket assets such as the environment, combined with the unprecedented availability of high-resolution data, has renewed broad interest in quantifying sustainability at different spatial levels. Policy-related decision making requires that potential sustainability measures meet three key requirements: (i) sustainability metrics need to be comprehensive so that they reflect the experience of representative households, (ii) sustainability indices need to be comparable across different geographic scales, and (iii) measures of sustainability need to be economically meaningful, ideally tying into the larger system of national accounts. However, conventional sustainability indices do not tend to meet these criteria, which renders them inappropriate for public-policy efforts. The subjectivity and theoretical inconsistency of common sustainability indices presents the biggest obstacle for their adoption as valid public policy targets. This article introduces an urban sustainability index that is based on a theoretically consistent, empirical measure of quality of life. Specifically, this article shows that greenness of cities has a strong positive correlation with urban quality of life, suggesting that the greener the city, the nicer a place to live it is. This is largely because energy efficiency is capitalized into economic activity and ultimately into urban quality of life. This relationship appears to hold across cities of all sizes, clearly emphasizing the direct link between progressive environmental policy and locational desirability. The takeaway message is straightforward: More "greenness" correlates to higher quality of life in urban areas.

"We must slow the rush to public acceptance of urban disamenities . . . as the defenders of the great cities we take Faustian positions; we see the positive values of civilization flowing from them." (Alonso 1976, p.54) 


\section{Quantifying Sustainability for Public Policy}

Climate change is expected to have significant economic impacts and is generating the near term-need for sizeable investments in infrastructure, mitigation and preparedness projects. Yet because the transition to sustainable growth and the comprehensive reduction of $\mathrm{CO}_{2}$ greenhouse gas emissions from growth-related energy consumption carry all the hallmarks of public goods, these goals will not be achieved by private sectors alone. Instead, there is an active role for public policy. From the perspective of policy makers, however, the prioritization of such large investment needs is very complex and fraught with a number of implementation challenges. To make matters worse, the recent financial crisis has left federal, state and particularly municipal governments in a state of fiscal crisis with very little capacity to make the necessary investments to achieve de-carbonization in the housing sector, transportation and public infrastructure.

All too often, projects that require large financial commitments are ignored, crowded out by the near-term urgency of competing public expenditures, jeopardizing long-term de-carbonization with complex intergenerational cost-benefit tradeoffs. In order to operationalize these trade-offs in terms of public policy objectives, policy makers need reliable instruments and well-specified, quantifiable targets for sustainability. Indeed, at all levels of government, policy relies on a variety of indicators when defining policy targets. For example, the Federal Reserve depends on the Consumer Price Index (CPI) and unemployment rates from the Bureau of Labor Statistics (BLS) when defining what combination of price stability and employment levels should guide its stance on monetary policy. ${ }^{1}$ Similarly, the Department of Education uses academic performance indices such as Adequate Yearly Progress to gauge the quality of local public schools. In short, well-defined key performance indicators are an indispensable tool for the conduct of public policy.

In the context of sustainability, however, it is less clear what the appropriate indices for policy ought to be. This is largely due to the broad definitional scope of the term sustainability itself; conceptually, at least, sustainability indices rely on a broad range of indicators that can usually be grouped into three categories: economic indicators such as employment, energy consumption or local food sufficiency; environmental indicators such as standards for clear air, for clean water or for waste; and social indicators such as crime, educational attainment or health out-

1. Detailed definitions of the most important technical terms and concepts used in this article are provided in the glossary in the appendix. 
comes. ${ }^{2}$ At the same time, policy-related decision making requires that individual indicators be aggregated into a single, composite index in order to obtain a clear signal that public policy can act upon. Despite increasing attempts to quantify the greenness of cities, these efforts remain largely without a firm theoretical anchor, which renders them unsuitable for policy purposes. For example, recent research initiatives such as the Economist Intelligence Unit's (2009) European Green City Index or the Urban Sustainability Index produced by the Urban China Initiative (2010) both apply weighting schemes that merely reflect the index providers' own subjective preferences instead of objective economic conditions. Similar efforts also exist for localities in the United States, ranging from the SustainLane US Cities Sustainability Rankings, to the Siemens US \& Canada Green Cities Index (Economist Intelligence Unit 2011), the U.S. Environmental Protection Agency's Energy Star Buildings Rankings and the proposed STAR Community Index. ${ }^{3}$ Despite their intuitive appeal, each of these sustainability indices uses a different methodology, which tends to produce dissimilar, often counterintuitive rankings. Matters are complicated further because these indices also tend to have sparse coverage, often ranking only a limited sample of the largest metro areas. By the same token, spatial aggregation for these popular indices, say to the state level, is not only intrinsically complex (Custance and Hillier 1998) but might also involve ethical considerations, such as social justice (Permanyer 2012). Thus, the subjectivity and theoretical inconsistency of existing sustainability indices presents the biggest obstacle for their adoption as valid public policy targets.

This article provides an overview of recent theoretical developments that outline a practical solution to the problem of constructing an objective measure of sustainability that can be used for public policy. Specifically, I discuss the relationship between an ideal urban sustainability index (USI) and market-based measures of urban quality of life as an alternative to popular sustainability rankings. The central issues of this article- that is, why conventional urban sustainability indices are not suitable for policy and how an objective measure of sustainability is related to urban quality of life- are best introduced by comparing conventional sustainability rankings to our objective sustainability measure, the imputed market-based

2. At the level of national policies, the UN Indicators of Sustainable Development (United Nations 2007) represent the most comprehensive benchmark for the formulation of national sustainable development policies. The World Bank's Eco2Cities program (Suzuki et al. 2010) attempts to develop a set of pragmatic benchmarks for national policies of sustainable urban development.

3. The STAR Community Index, which is being developed by ICLEI-Local Governments for Sustainability (in partnership with the U.S. Green Building Council, the National League of Cities, and the Center for American Progress), is due for release in late 2013 . 
proxy for sustainability. Columns (1), (4), and (5) of Table 1 record the top- and bottom-ranked cities according to three conventional sustainability indices listed above. For the first set of these green city rankings, column (2) also lists a marketbased measure of quality of life (QOL) that is expressed as the annual implicit average household expenditures for local amenities. For comparative purposes, Table 1 also lists a survey-based measure of subjective well-being in column (3). Three key themes emerge from this table. First, there is the issue of comparability. Despite some correlation, the conventional sustainability rankings are not directly comparable, mainly because they use different indicators and methods to rank a small sampling of cities. Second, these conventional rankings are not representative. This means that it is not clear to what extent, if at all, the rankings reflect the experience of average households for a given geographic area. Lastly, there is the issue of the economic relevance of the rankings. Because these popular rankings are ordinal, it is not possible to compare differences in rankings, say, the difference between the levels of sustainability of the highest- and lowest-ranked city, in any way that is meaningful for policy. Specifically, this means that is not possible to compare how sustainable

TABLE 1: Sustainability rankings and quality of life

\begin{tabular}{lcccc}
\hline $\begin{array}{l}\text { Siemens-EIU Green } \\
\text { Cities Rankings }\end{array}$ & QOL* & GHI** & $\begin{array}{c}\text { SustainLane } \\
\text { Rankings }\end{array}$ & $\begin{array}{c}\text { EPA EnergyStar } \\
\text { Rankings }\end{array}$ \\
\hline$(1)$ & $(2)$ & $(3)$ & $(4)$ & $(5)$ \\
\hline $\begin{array}{l}\text { Top-ranked cities } \\
\text { San Francisco }\end{array}$ & $\$ 7,176$ & 1.26 & Portland & Los Angeles \\
New York & $\$ 4,941$ & -0.32 & San Francisco & Washington \\
Seattle & $\$ 5,973$ & 0.65 & Seattle & Atlanta \\
Denver & $\$ 3,590$ & 0.70 & Chicago & Chicago \\
Boston & $\$ 3,807$ & 0.79 & New York & San Francisco \\
& & & & \\
Bottom ranked cities & $\$ 3,995$ & -0.18 & Memphis & Miami \\
Pittsburgh & $\$ 3,143$ & 0.38 & Las Vegas & San Diego \\
Phoenix & $\$ 5,831$ & -0.09 & Tulsa & Detroit \\
Cleveland & $\$ 2,324$ & -0.41 & Oklahoma City & San Jose \\
Saint Louis & $\$ 1,187$ & -0.74 & Mesa & Portland \\
Detroit & 363 & 187 & 50 & 21 \\
N. Obs: 22 & & & & \\
Correlation with Siemens- & & & \\
$\quad$ EIU Rankings & 0.7676 & 0.4472 & & \\
\hline
\end{tabular}

Notes: To ensure comparability all index rankings in columns (1), (4) and (5) are for the year 2011. *Marked-based quality of life (QOL) for each metropolitan statistical area is expressed as the annual implicit average household expenditures for local amenities (see Bieri, Kuminoff and Pope (2013) for more details).

${ }^{* *}$ Standardized values of the 2011 Gallup-Healthways Well-Being Index, a large-scale daily assessment of U.S. residents' health and well-being (see http://www.well-beingindex.com/) 
San Francisco is according to the EnergyStar index versus the Siemens-EIU index, nor is it possible to say anything meaningful about how much more sustainable a city ranked 2 is over a city ranked 3 for a given index. For the same reasons, changes in the rankings over time are equally difficult to interpret.

By contrast, the QOL measure of sustainability listed in column (2) of Table 1 avoids these drawbacks altogether; it covers the entire universe of U.S. metropolitan statistical areas; it is derived using data from official sources; it characterizes the average experience of representative households while accounting for local difference in the cost of living; and it is expressed in terms of implicit expenditures on local amenities, permitting economically meaningful comparisons with other categories of household expenditure as well as comparisons across time and space.

The remainder of this article proceeds as follows. The next section discusses the link between policy-apt green indices and efforts to expand the national income and products accounts to include nonmarket goods, such as environmental and cultural amenities, local public goods and infrastructure that are integral components of sustainability. Section three then turns to the practical challenge of implementing a quality-of-life-based measure of sustainability in practice. Finally, this paper addresses the practical characterization of urban sustainability using a USI that relies on economic theory to derive quality-of-life thresholds.

\section{Nature's Numbers: Accounting for Amenities and the Nonmarket Economy}

From a theoretical perspective, a policy-relevant measure of sustainability should be directly grounded in the national income and product accounts (NIPA), since they are also the source of other objective measures that guide much of public policy. The NIPA arguably represent one of the "greatest innovations in economics" (Jorgenson 2009); they are the national equivalent to a corporation's balance sheet and provide a snapshot summary of different aspects of the national economy. Operationally, the NIPA form the backbone for the tabulation of such metrics as GDP, personal consumption expenditure and net exports of goods and services. While they were originally conceived to include all elements that can "be brought directly or indirectly into relation with the measuring rod of money" (Pigou 1920), operationalizing the NIPA has led to market-based measures of economic performance that track private consumption rather than social welfare. As a consequence, economists 
have long recognized the potential value of expanding national accounts to provide a richer description of nonmarket activity (Kuznets 1934; 1946). Indeed, traditional measures of economic activity, such as GDP, do not fully reflect the impact of urbanization and agglomeration. Perhaps most importantly, in the context of sustainability, GDP does not account for the negative externalities associated with environmental degradation and the depletion of natural resources that went hand in hand with much of the process of economic development since the Industrial Revolution.

\subsection{The Rise of "Green Accounting"}

Motivated by the need to include sustainability metrics in the public policy discourse, Nordhaus and Tobin (1972) provided an early attempt to adjust NIPA for the value of leisure time and nonmarket, environmental activity. Their analysis stimulated a great deal of interest at the time as well as subsequent work. The growing importance of environmental issues has renewed broad interest in "green accounting." These efforts have culminated in the ground-breaking work on the Integrated Environmental and Economic Satellite Accounts (IEESA) at the U.S. Bureau of Economic Analysis (BEA) and a series of subsequent recommendations to develop nonmarket accounts for the U.S. by both the National Research Council's Committee on National Statistics (National Research Council 1999; 2005) and the NBER (Jorgenson, Landefeld, and Nordhaus 2006; Jorgenson and Landefeld 2009). ${ }^{4}$ Similar endeavors in China have led to the much-debated pilot project of the 2004 China Green National Economic Accounting Study Report.

Despite these conceptual advances, however, applied progress with regard to a "greening" of the NIPA has remained rather limited. The main impediment to progress in this matter can be attributed to two central challenges: first, there is the need for reliable data on nonmarket quantities, and second, there is the inherent difficulty of imputing prices for these nonmarket goods and services. While environmental economists have made progress on dealing with households' willingness to pay for specific amenities such as air quality (Chay and Greenstone 2005; Bayer, Keohane, and Timmins 2009; Muller, Mendelsohn, and Nordhaus 2011), a comprehensive set of "green" adjustments to NIPA (or a full set of green satellite accounts) remains elusive. ${ }^{5}$

\footnotetext{
4. So-called satellite accounts are intended to supplement existing national accounts, maintaining both flexibility of definitions and methods (Carson 1994). See also Nordhaus (2000) and Abraham and Mackie (2006).

5. Banzhaf (2005) and Boyd (2007) are notable exceptions.
} 


\subsection{Sustainability Indicators as Policy Targets}

Against the backdrop of these environmental accounting efforts, adequately quantifying urban sustainability presents one of the most imminent challenges that urban policy makers need to tackle. ${ }^{6}$ Put differently, this raises the question of what conventional measures of households' living standards miss when urban disamenities are ignored over periods of rapid industrialization or urbanization. In many ways, global concerns about climate change and its immediate impacts on cities have given new currency to the pessimists' view of the process of urbanization, eternalized in the poet William Blake's reference to the "dark Satanic mills." As the threat of serious disruption to long-term climate patterns and rising sea levels seems to become an uncomfortable environmental reality, the quality of urban life for urban residents might once again be decreasing instead of increasing. In other words, there is a renewed urgency for a careful disentangling of the economic and social benefits of urbanization from their environmental cost.

While sustainability indicators play a central role in this process, indicators by themselves do not define environmental policy or a self-contained policy goal. Yet indicators provide the necessary baseline against which policy can be formulated. At the same time, the broad class of sustainability indicators is most fundamentally challenged by the immeasurability critique and definitional issues related to the concept of sustainability itself. ${ }^{7}$ At the core of this issue is how well-if at allsustainability can be measured. The definition of sustainability in the oft-cited Brundtland Report (1987) perhaps best illustrates the (im)measurability dimension of this problem; the report defines sustainable development as development that meets the needs of present generations without compromising the well-being of future generations. But neither of those needs is specified, nor is the balance that attains intergenerational equity explicitly defined.

In an attempt to define the concept of sustainability more precisely, economists have developed a wide-ranging array of tractable definitions of sustainability. Hart-

6. The "Commission on the Measurement of Economic Performance and Social Progress" (CMEPSP 2009) was convened by French president Nicholas Sarkozy and headed by Nobel laureates Joseph Stiglitz and Amartya Sen. Its final report identifies the reliable measurement and monetary valuation of changes in environmental quality or intangible fixed assets such as public goods as a major hurdle towards a more suitable metric of well-being. Fleurbaey (2009) provides a comprehensive overview of the debate on alternatives to GDP, specifically examining different approaches that focus on sustainability, happiness, social choice and fair allocation, and capability.

7. See, e.g. Böhringer and Jochem 2007; Bell and Morse 2008; Heal 2011 for an extensive discussion of the immeasurability critique of sustainability indicators. Furthermore, beyond simply producing rankings that reflect the negative externalities of economic activities, subnational (urban or regional) sustainability metrics might be inconsistent with larger national aggregates of flow- and stock-based macroeconomic measures of sustainability (Hanley 2000). 
wick's (1977) rule holds that an economy can be sustained if the value of the total, net investment (i.e., total fixed investment minus depreciated replacement) is zero. Because conventional market-based prices do not reflect important nonmarket activity, Hartwick's zero-net investment rule relies on "green" national accounting as described above to be implementable. In other words, the Hartwick zero net investment rule implies that the sustainable amount of public and private investments in green projects should at least equal current and future costs from environmental degradation. Similarly, Solow's (1993) definition characterizes sustainability as the level of economic activity that substitutes man-made capital and knowledge for natural capital and-like Hartwick's rule-requires augmented, green national accounts to fully reflect how well society is doing in sustaining itself. Extending these definitions of economic sustainability, Neumayer (2010) introduces the notion of "weak" versus "strong" sustainability. The former concept implies constant utility with substitutability between man-made capital and natural capital (i.e., in the sense of Solow), whereas the latter concept disallows substitutability altogether.

However, despite these theoretical advances in pinning down a policy-relevant definition of sustainability, large-scale empirical applications of comprehensive sustainability targets for policy purposes remain elusive, largely for the reasons discussed above, i.e., for a lack of high-resolution, time-consistent data on quantities that matter for urban sustainability and a corresponding set of (imputed) prices for these quantities.

\section{From Theory to Practice: Linking Urban Sustainability and the Cost of Living}

At first sight, disentangling mutual causation between sustainability and quality of life is complicated by the fact that neither sustainability nor quality of life is directly observable, which renders them both elusive targets for policy. Yet despite these challenges, progress in quantifying urban sustainability for public policy is not necessarily beyond practical reach. The pivotal element in such an undertaking is a closer examination of the empirical link between urban environmental quality, sustainability and quality of life. Indeed, important theoretical and empirical progress has been made in the hedonic valuation literature with regard to improving estimates of urban quality of life. ${ }^{8}$ Because the methodology in this literature has

8. See Bieri (2010) for an overview. The key insight of this literature rests on the observation that location-specific differences in wages and (land) rents should compensate for the differences in nonmarket characteristics, such as natural 
direct parallels to the methodology for producing an optimal urban sustainability index, empirical quality-of-life measures could serve as second-best proxies for urban sustainability. Conceptually, therefore, the regional measures of aggregate urban sustainability must tie in directly with the logic of "green" asset and production accounting of IEESA in the same way that measures for inflation, such as the GDP deflator or the chain price index for personal consumption expenditures (PCE), are direct by-products of NIPA. ${ }^{9}$ To the extent that targeting urban quality of life is consistent with urban sustainability, green cities are therefore also nice places to live. However, the relative magnitude of this relationship ultimately remains an empirical issue which is explored in the next section.

From a technical perspective, any measurement of urban sustainability should therefore fall into the more general class of cost-of-living indices that measure changes in the amount that consumers need to spend to reach a certain utility level or standard of living that is consistent with sustainability. Because such measures also take into account changes in environmental and other nonmarket factors that affect consumers' well-being, this would narrow the gap between an ideal cost-ofliving index (e.g., as defined by Klein and Rubin 1948) and the currently available price indices. Technically, the urban sustainability index should thus be conceptualized as a traditional price-quantity index, much like other economic indices such as the BLS's CPI-U or the BEA's GDP and PCE deflator. ${ }^{10}$

Practically, this implies two specific challenges for the implementation of the USI. First, we need to identify and quantify appropriate measures for the quantities (i.e., the relevant nonmarket or near-market goods), and second, we need to derive a set of theoretically consistent imputed equilibrium prices which will serve as valuation weights. Simultaneously, geographical granularity and scope must allow for both interurban and intraurban comparisons. This means that the index should be based on data with the highest possible resolution (e.g., microdata on households, parcels and census tracts for amenities). Correspondingly, the USI should maximize relevance and representativeness by targeting the metropolitan statistical area as its underlying spatial level of aggregation-this follows naturally from the fact that metropolitan statistical areas reflect households' residential and labor market

or cultural amenities that increase the attractiveness of a given locality. Thus, although geographic disparities in the quality of life themselves are unobservable, they can be measured by prevailing wage differentials with the local cost of living netted out.

9. There are two broad indices of consumer prices: the consumer price index (CPI) and the PCE. See Clark (1999) and Garner et al. (2006) for a good overview of the theoretical relationship between the CPI and the PCE deflator.

10. Irving Fisher's (1922) index number theory provides the intellectual framework for this family of indices. See Diewert $(1976$; 1978) for a comprehensive discussion of the theoretical properties of such indices. See glossary for more details on different price indices. 
choices and their resulting spatial economic linkages. While urban heterogeneity does not depend on city size alone, it might be difficult to gain meaningful insights on the relative differences in the sustainability between two locations when giving the same observational weight to a one-county metro like Ann Arbor and to a diverse metro area like Detroit, which spans some of the nation's most affluent counties (e.g., Oakland County) as well as one of the poorest U.S. Congressional Districts (the 13th Congressional District, MI which includes the city of Detroit). At the same time, the methodological design of the USI should follow established best practices such that it is applicable to a broader "green cities" context (Kahn 2006a; Kahn 2006b; Kahn 2010).

In sum, widely observed practices among both statistical agencies and commercial index providers thus suggest the following generally accepted principles by which a sustainability index should abide:

- Scope and coverage: The index should reflect the experience of representative households for a given geographic area; the index should also be geographically representative and should be as broad and inclusive in its scope as possible.

- Transparency and reproducibility: The index performance should be reproducible; as far as possible, objective rather than subjective criteria should be used in selecting the data. At a minimum, the source of the underlying data should be published; the index should be valid over a reasonably long time horizon.

\section{Green Cities, Urban Sustainability and the Quality of Life}

Before exploring the empirical evidence for the relationship between urban sustainability and the quality of life, it is worth examining how urban economists generally think about the relative importance of different factors to household well-being, usually expressed as utility. The key insight of this literature rests on the observation that location-specific differences in wages and (land) rents should compensate for the differences in non-market characteristics, such as natural or cultural amenities that increase the attractiveness of a given locality. Thus, although geographic disparities in the quality of life themselves - much like sustainability - are unobservable, quality-of-life differentials can be measured by prevailing wage differentials with the local cost-of-living netted out. Since the work of Rosen (1979), Haurin (1980) and Roback (1982; 1988), a growing body of literature has tried to produce 
theoretically consistent quality-of-life rankings for urban areas by deriving wage and rent differentials via hedonic methods, calculating the implicit prices of locationspecific amenities which are then used as utility valuation weights. ${ }^{11}$ While this early literature focuses on interurban differences and treats cities as spatially homogenous entities, extensions by Hoehn, Berger, and Blomquist (1987) incorporate urban structure and intraurban location into the quality-of-life framework and allow for amenity variation both within and across urban areas. In this setting, the relationship between quality of life and urban size remains an empirical matter, ultimately determined by the precise nature of these agglomeration effects and the relative impact of (dis)amenities on production and consumption. If a household amenity also reduces unit production costs of firms (e.g., public infrastructure), the comparative statics of the Rosen-Haurin-Roback model imply that the quality of life unambiguously increases with city size, irrespective of whether the agglomeration effects have a positive or negative impact on productivity. ${ }^{12}$

However, recent empirical quality-of-life estimates that conform with economic theory seem difficult to reconcile with the popular suggestion that the quality of life is an increasingly important driver of urban development patterns, a claim that rests on the hypothesis that the demand for consumption amenities has grown as incomes and education levels have risen nationwide (Glaeser, Kolko, and Saiz 2001). Indeed, while firm productivity advantages continue to dominate amenities in most metropolitan areas, the relative importance of amenities appears to have increased between 1990 and 2000 (Deitz and Abel 2008). ${ }^{13}$ It is thus perhaps not surprising that existing hedonic quality-of-life rankings have been faulted for their lack of intuitive appeal and their tendency to produce apparent misrankings (Rappaport 2008). The problem is that these estimates suffer from an index number analog to the classic omitted variable problem. This helps to explain why past estimates often seem counterintuitive, a criticism that is compounded by the fact that past rankings bear no resemblance to the quality-of-life rankings produced in the popular press. ${ }^{14}$

11. See, for example, Gyourko, Kahn, and Tracy (1999), Blomquist (2006) and Lambiri, Biagi, and Royuela (2007) for comprehensive surveys of the literature.

12. A string of prominent papers-including Blomquist, Berger, and Hoehn (1988), Gyourko and Tracy (1991) and, most recently, Chen and Rosenthal (2008)_produce quality-of-life rankings that are negatively related to city size. Albouy (2008) is a notable exception in this regard. At a minimum, this research suggests that the bulk of amenities that contribute to quality of life is at best unproductive from the firm's perspective, possibly even pointing to the presence of productivity-reducing congestion effects. Put differently, households and firms do not appear to have the same preferences for city size (Gabriel and Rosenthal 2004).

13. Local productivity does not have to be the main driver of urbanization. Rappaport (2009) shows that the growing importance of quality-of-life differentials can eventually cause local amenities to become the sole determinant of relative local density.

14. The correlations with the rankings of the 1981 PlacesRated Almanac are -0.180 for the rankings in Roback (1982), 
To overcome this problem, I construct a set of estimates for implicit prices of non-market goods in each metropolitan area, relying on a unique dataset of countylevel amenities in combination with an econometric methodology that is developed in Bieri, Kuminoff, and Pope (2013, BKP hereafter). The BKP dataset describes a wide variety of geographic and climate characteristics, environmental externalities, local public goods, infrastructure characteristics, and cultural and urban amenities. Specifically, this dataset tracks some 70 county-level amenities, ensuring a more nuanced differentiation in terms of how locations vary with regard to the underlying determinants of the quality of life (see appendix B for a complete list of the amenity variables). This rich set of amenities thus minimizes the omitted variable bias of the aggregate index and permits a more accurate attribution of what portion of the spatial variation in implicit quality-of-life expenditure is due to the broadest possible set of local differences in nonmarket goods.

The estimates from the BKP national model suggest that these effects are economically significant, given that the average American household sacrificed around $\$ 6,000$ during the year 2000 in order to consume the bundle of spatially delineated amenities conveyed by their preferred location. At the national level, this accounts for approximately $8 \%$ of personal consumption expenditures, but there is significant variation across Census Divisions which ranges from less than $5 \%$ in the East South Central states (AL, KY, MS, TN) to over $25 \%$ in the states of the Pacific (CA, OR, WA) (see BKP for more details).

Using these empirical quality-of-life estimates reveals the tension between sustainability and quality of life, which is illustrated in Figure 1. The annual cost of carbon dioxide emissions per household from driving, public transit, home heating, and electricity usage is plotted on the vertical axis and metropolitan quality of life is shown on the horizontal axis. While the lowest emissions areas are generally in California and the highest emissions areas are in Texas and Oklahoma, this graph highlights that the presence of emissions has a strong negative correlation with urban quality of life, i.e., the greener the city, the nicer a place to live it is. This is because energy efficiency is widely capitalized into economic activity and ultimately into urban quality of life. At the same time, however, this relationship appears to hold across cities of all sizes, clearly emphasizing the direct link between progressive environmental policy and locational desirability.

All else equal, Figure 1 thus supports the hypothesis that greener cities enjoy a greater quality of life. The statistical reliability of the relationship between sus-

-0.044 for those in Blomquist, Berger \& Hoehn (1998), -0.051 for those in Gyourko \& Tracy (1991) and-compared to the 2007 PlacesRated Almanac — the corresponding correlation for Chen \& Rosenthal is - 0.026 . 


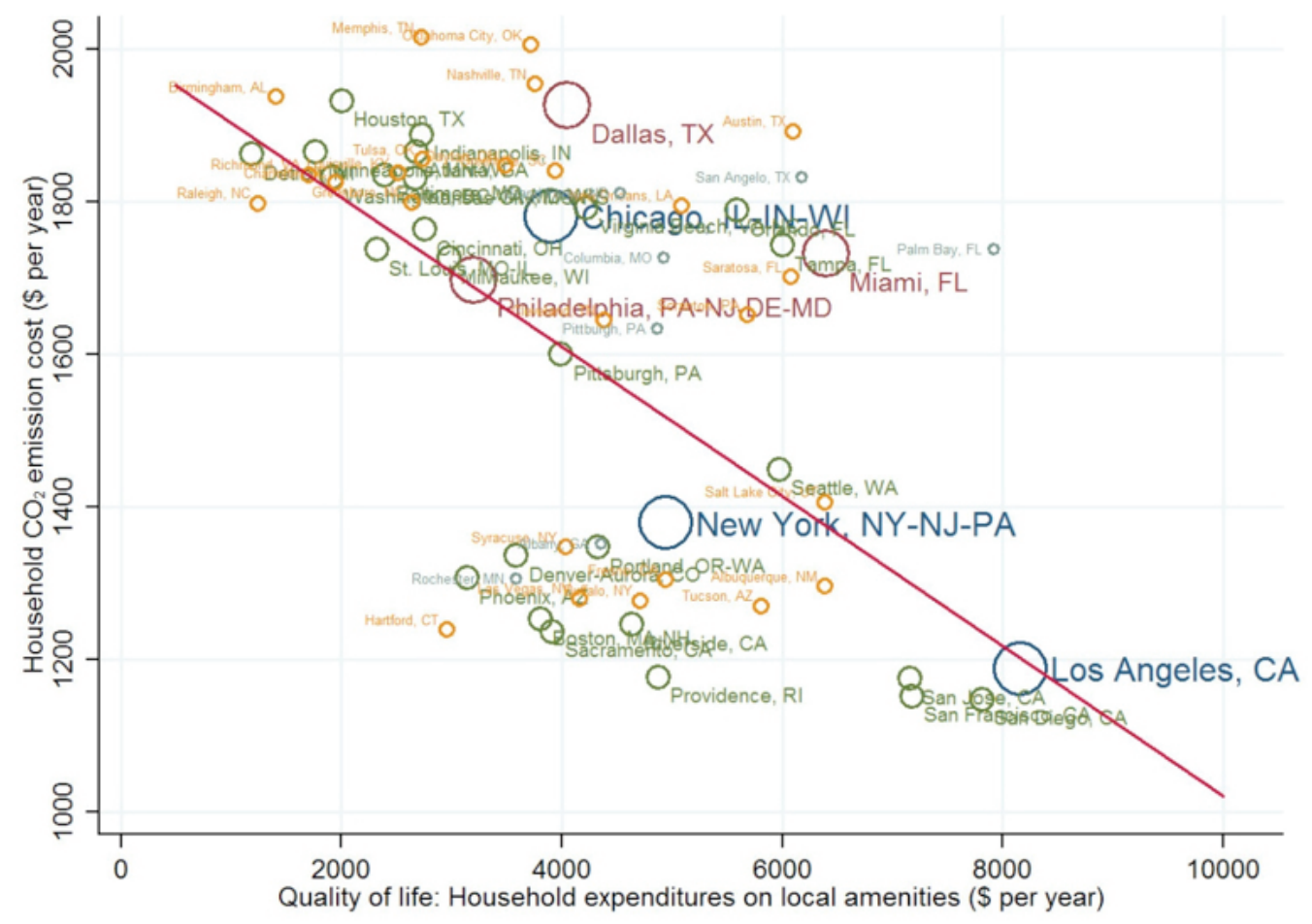

Figure 1: The greenness of cities and their quality of life

Notes: Quality of life (QOL) for each MSA is measured by deriving wage and rent differentials via hedonic methods, calculating the implicit prices of location-specific amenities which are then used as utility-valuation weights. The $\$$ amounts represent the annual implicit average household expenditures for local amenities (see text for more details). The fitted line is obtained from a weighted regression using population weights for each MSA and is given by $\mathrm{CO}_{2}=2,001.72-0.0979 \cdot \mathrm{QOL}$ with a $t$-statistic $=-7.15$ for the slope coefficient and an adjusted $R^{2}=0.4521$, where $\mathrm{CO}_{2}$ is the annual cost of carbon dioxide emissions and $\mathrm{QOL}$ is household expenditures on local amenities. Sources: Author's calculations using data from Bieri, Kuminoff and Pope (2013) and Glaeser and Kahn (2010).

tainability and quality-of-life-related expenditures in its most simple specification is illustrated by the regression line in Figure 1. More robust specifications of the sustainability-QOL relationship increase the overall explanatory capacity of amenity-related expenditures to over $90 \%$ of the variation of the annual cost of $\mathrm{CO}_{2}$ emissions across U.S. cities. ${ }^{15}$ In other words, inferring an amenity-based measure of expenditures that are associated with local quality of life provides a highly

15. Alternative specifications for the sustainability-QOL relationship take the form $\mathrm{CO}_{2}=\alpha+\beta \mathrm{QOL}+\gamma X+\varepsilon$, where $X$ is a set of controls that include, depending on the specification, metro-level population, the Gallup-Healthways well-being index and Census Division indicators. In the preferred specification, all regressors enter significantly with an adjusted $\mathrm{R}^{2}=0.9190$. 
accurate predictor for urban sustainability, proxied here by the household-level cost of $\mathrm{CO}_{2}$ emissions. Perhaps most importantly in the context of obtaining a policy benchmark, sustainability thus quantified meets all the scope, coverage, transparency and reproducibility criteria introduced in the previous section.

The relationship between land-use regulation and quality of life provides an additional plausibility check for the link between urban sustainability and amenitydriven quality of life that forms the main assertion of this paper. From a sustainability perspective, open space represents one of the primary environmental concerns in urban areas. Land-use regulation thus has a direct influence on the quality of life in urban areas by the way in which it influences the shaping of the built environment. The restriction of housing supply due to zoning regulation is perhaps one of the most significant channels through which local governments have a direct effect on the forces of urban agglomeration, especially in a country like the United States with significant local variation in land-use and other regulatory practices. ${ }^{16}$ The related issues of growth management and the provision of landscape amenities also play a central role in the policy mix of local governments and have important consequences for regional disparities in the quality of life.

Figure 2 plots the relationship between the strength of land-use regulation and the quality of life in urban areas. The substantial amount of positive co-variation between the two variables suggests that locations with a more restrictive land-use regime are also more desirable in terms of the quality of life. Again, this relationship does not appear to be significantly dependent on urban size, although the most restrictively regulated localities are smaller towns in New England where home-rulespecific aspects of land-use regulation afford municipalities a substantial amount of self-determination. While cities in the West traditionally tend to be the least regulated, anti-sprawl land-use regulation in California (e.g., the state's Senate Bill 375) and the distinct policy innovations of the Pacific Northwest (e.g., Portland's urban growth boundary) tend to coincide with a higher quality of life. Because of the popular notion that more restrictive land-use regulation might lead to higher house prices, there could be the worry that quality-of-life metrics are artificially inflated in areas with tighter regulation. However, recent evidence by Glaeser and Ward (2009) dispels such concerns showing that more stringent regulations are associated with higher prices only when contemporary density and demographics are not controlled for, but not when these contemporaneous controls are added.

16. Green, Malpezzi, and Mayo (2005) find strong evidence that differences in supply elasticities indeed stem mainly from differences in urban form and urban land-use regulation. 


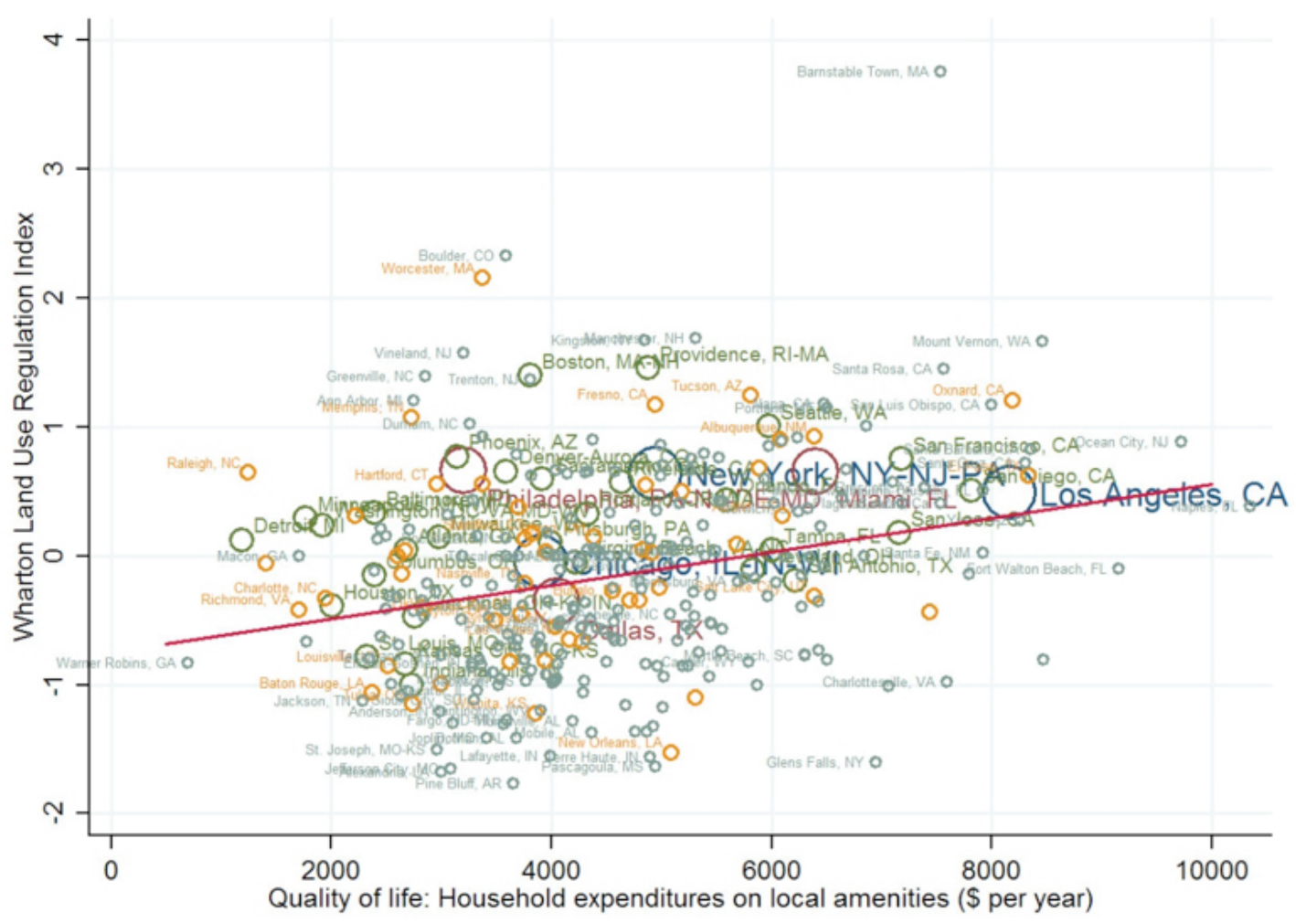

Figure 2: Quality of life and land-use regulation

Notes: The Wharton Residential Land Use Regulation Index (WRLURI) provides an aggregate measure of regulatory constraint on development that allows us to rank areas by the degree of control over the residential land-use environment. MSA-level values of the WRLURI were constructed from town-specific indices. The fitted line is obtained via a weighted regression using population weights for each MSA and is given by WLURI $=0.8183+0.0634 \cdot \mathrm{QOL} \cdot 10^{-3}$ with a $t$-statistic $=2.30$ for the slope coefficient and adjusted $\mathrm{R}^{2}=$ 0.3612. Sources: Author's calculations using data from Bieri, Kuminoff and Pope (2013) and Gyourko, Saiz, and Summers (2008).

\section{Outlook}

Beyond its theoretical origins discussed in this paper, the relationship between quality of life and sustainability is also closely linked to the notion of identifying an "optimally sized" urban area, i.e., cities where size-related amenities and disamenities are balanced. This raises similar questions, such as whether there is a trade-off between growth and sustainability, and if so, what are the short-run versus long-run dynamics? What portion of earnings of urban residents may simply be compensation for the negative externalities of urbanization? As green cities might experience 
higher pressures on house prices, what are the linkages between sustainability and affordable housing?

While rapid urbanization at a global level has unquestionable implications for local and national policies, local histories and path-dependent economic geographies matter equally for sustainability. The USI introduced in this paper should provide a practical tool that is able to inform the public policy discourse on sustainability in a tractable way; overcoming common limitations of existing efforts that quantify urban sustainability, the quality-of-life-based implementation of the USI simultaneously conforms to best practices of index construction and is capable of reflecting the idiosyncrasies of individual cities. Given the complexity of the revitalization challenges of Rustbelt cities or the trials of growth management for Sunbelt cities, an amenity expenditure measure such as the one presented here offers a sufficiently flexible and transparent benchmark for policy makers to rank sustainability-related public investments. Lastly, the approach put forward in this article also underscores the practical feasibility of environmental accounting in an integrative way.

\section{A. Glossary}

This glossary focuses on key terms appearing in the main text that are too specialized to be explained there.

Brundtland Report: Formally known as the World Commission on Environment and Development (WCED), the Brundtland Commission-named after its Chairman Gro Harlem Brundtland-was constituted by the United Nations in December 1983 with the aim of uniting countries in pursuit of sustainable development. Brundtland was the former Prime Minister of Norway and was chosen due to her strong background in the sciences and public health. The Brundtland Commission officially dissolved in December 1987 after releasing the Brundtland Report, also known as Our Common Future, in October 1987. The publication of the Brundtland Report marks a watershed moment in achieving a multinational consensus in defining sustainability with a view to formulating public policy.

Consumer Price Index (CPI): The U.S. CPI is a time series measure of the price level of consumer goods and services calculated by the Bureau of Labor Statistics (BLS) on a monthly basis. The BLS routinely computes different versions of the CPI that are used for different purposes. For example, the Consumer Price Index for All Urban Consumers (CPI-U) is representative of the buying habits of 
approximately 80 percent of U.S. households that live in Metropolitan Statistical Areas (MSAs) and in urban places of 2,500 inhabitants or more.

Gross Domestic Product (GDP): Gross domestic product (GDP) is the most widely used measure of U.S. output. It is defined as the market value of the goods and services produced by labor and property located in the United States. Because the labor and property are located in the United States, the suppliers (that is, the workers and, for property, the owners) may be either U.S. residents or residents of the rest of the world.

Index number theory: Price index formulas can be evaluated based on their relation to economic concepts (like cost of living) or on their mathematical properties. Several different tests of such properties have been proposed in index number theory literature, which was pioneered by the American economist Irving Fisher (1867-1947).

Metropolitan Statistical Area (MSA): Metropolitan Statistical Areas (metro areas) are geographic entities delineated by the Office of Management and Budget $(\mathrm{OMB})$ for use by federal statistical agencies in collecting, tabulating, and publishing federal statistics. A metro area contains a core urban area with a population of 50,000 or more (an urban core of at least 10,000 but less than 50,000 is referred to as micropolitan statistical area). Each metro or micro area consists of one or more counties and includes the counties containing the core urban area, as well as any adjacent counties that have a high degree of social and economic integration (as measured by commuting to work) with the urban core.

National Income and Product Accounts (NIPA): The national income and product accounts (NIPAs) are produced by the Bureau of Economic Analysis (BEA). Much like the balance sheet, the profit and loss account and cash flow statements that provide accounting summaries on the economic position of corporations, the NIPAs are a set of economic accounts that provide information on the value and composition of output produced in the United States during a given period and on the distribution and uses of the income generated by that production. A central feature of the NIPAs is gross domestic product (GDP), which measures the value of the goods and services produced by the U.S. economy in a given time period.

Price Deflator: Among price indices, a price deflator is the ratio of the currentdollar value of a price index series to its corresponding chained-dollar, real value. For example, the GDP deflator measures the ratio of nominal (or current-price) GDP to the real (or chain volume) measure of GDP, i.e., it is defined as (Nominal GDP / Real GDP)*100. 
Rust Belt: The Rust Belt usually refers to an area straddling the Midwestern and Northeastern United States plus small parts of the Upper South, in which local economies traditionally specialized in large-scale manufacturing of finished medium to heavy consumer and industrial products, including the transportation and processing of the raw materials required for heavy industry. Traditional Rust Belt cities are also characterized by a secular loss of population, and they include Detroit, MI, Cleveland, OH, Youngstown, OH, Pittsburgh, PA, Buffalo, NY and Rochester, NY.

Sun Belt: The Sun Belt is generally considered to stretch across the South and Southwest of the United States. One of the main defining features of the Sun Belt is its warm-temperate climate with extended summers and brief, relatively mild winters. Typical Sun Belt cities, such as Dallas, TX, Houston, TX, Miami, FL and Phoenix, AZ, have seen above-average population and income growth over the last five decades.

\section{B. Data on Amenities}

Table B1 summarizes the national county-level data that forms the basis for the imputed household expenditures on local amenities as developed in Bieri, Kuminoff and Pope (2013).

\section{Acknowledgements}

I am indebted to the editor, Nick Rajkovich, Julie Steiff and three anonymous reviewers for thoughful comments that have greatly helped to improve earlier drafts of this paper. Financial support for this research from the University of Michigan's Graham Environmental Sustainability Institute is also gratefully acknowledged. The usual disclaimers apply.

\section{References}

Abraham, Katherine, and Christoper Mackie. 2006. "A Framework for Nonmarket Accounting." In A New Architecture for the U.S. National Accounts, edited by Dale W. Jorgenson, J. Steven Landefeld, and William D. Nordhaus, 161-192. Chicago: University of Chicago Press.

Albouy, David Yves. 2008. "Are Big Cities Bad Places to Live? Estimating Quality-of-Life Across Metropolitan Areas." National Bureau of Economic Research Working Paper, Cambridge, MA. 
Alonso, William. 1976. “Urban Disamenities.” Society 13 (4): 51-53. http://dx.doi.org/10.1007/ BF02734812

Banzhaf, H. Spencer. 2005. "Green Price Indices." Journal of Environmental Economics and Management 49 (2): 262-280. http://dx.doi.org/10.1016/j.jeem.2004.05.006

Bayer, Patrick, Nathaniel Keohane, and Christoper Timmins. 2009. "Migration and Hedonic Valuation: The Case of Air Quality." Journal of Environmental Economics and Management 58 (1): 1-14. http://dx.doi.org/10.1016/j.jeem.2008.08.004

Bell, Simon, and Stephen Morse. 2008. Sustainability Indicators: Measuring the Immeasurable?, 2nd ed. London, UK: EarthScan.

Bieri, David S. 2010. "Location Choice, Linkages and the Spatial Economy: Theory, Evidence and Heterodox Assessment." PhD dissertation, Blacksburg, VA: School of Public \& International Affairs, Virginia Tech.

Bieri, David S., Nicholai V. Kuminoff, and Jaren C. Pope. 2013. "National Expenditures on Local Amenities." Unpublished mimeograph.

Blomquist, Glenn C. 2006. "Measuring Quality of Life.” In A Companion to Urban Economics, edited by Richard J. Arnott and Daniel P. McMillen, 483-502. New York: Blackwell Publishing. http://dx.doi.org/10.1002/9780470996225.ch28

Blomquist, Glenn C., Mark C. Berger, and John P. Hoehn. 1988. "New Estimates of Quality of Life in Urban Areas." American Economic Review 78 (1): 89-107.

Böhringer, Christoph, and Patrick E. P. Jochem. 2007. "Measuring the Immeasurable -- A Survey of Sustainability Indices." Ecological Economics 63 (1): 1-8. http://dx.doi.org/10.1016/j.ecolecon.2007.03.008

Boyd, James. 2007. "Nonmarket Benefits of Nature: What Should Be Counted in Green GDP?" Ecological Economics 61 (4): 716-723. http://dx.doi.org/10.1016/j.ecolecon.2006.06.016

Carson, Carol S. 1994. "Integrated Economic and Environmental Satellite Accounts." Survey of Current Business 74 (4): 33-49.

Chay, Kenneth Y., and Michael Greenstone. 2005. "Does Air Quality Matter? Evidence from the Housing Market." Journal of Political Economy 113 (2): 376-424. http://dx.doi. org/10.1086/427462

Chen, Yong, and Stuart S. Rosenthal. 2008. "Local Amenities and Life-cycle Migration: Do People Move for Jobs or Fun?” Journal of Urban Economics 64 (4): 519-537. http://dx.doi. org/10.1016/j.jue.2008.05.005

Clark, Todd E. 1999. "A Comparison of the CPI and the PCE Price Index." Federal Reserve Bank of Kansas City Economic Review 25 (1): 15-29.

CMEPSP. 2009. Report by the Commission on the Measurement of Economic Performance and Social Progress. Paris, France: Commission on the Measurement of Economic Performance and Social Progress.

Custance, John, and Hilary Hillier. 1998. "Statistical Issues in Developing Indicators of Sustainable Development." Journal of the Royal Statistical Society: Series A 161 (3): 281-290. http:// dx.doi.org/10.1111/1467-985X.00108

Deitz, Richard, and Jaison R. Abel. 2008. Have Amenities Become Relatively More Important Than Firm Productivity Advantages in Metropolitan Areas? Federal Reserve Bank of New York, NY.

Diewert, W. Erwin. 1976. "Exact and Superlative Index Numbers." Journal of Econometrics 4 (2): 115-145. http://dx.doi.org/10.1016/0304-4076(76)90009-9 


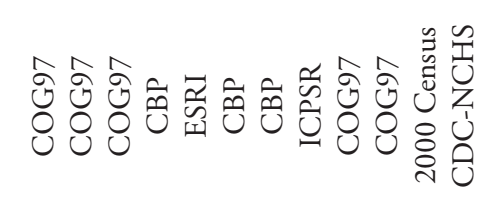

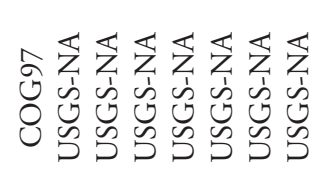

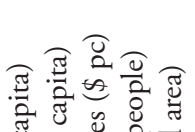
હ્๊

ปै

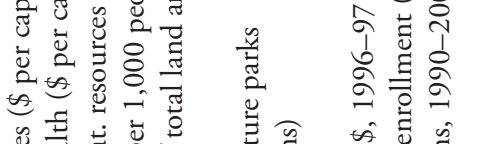

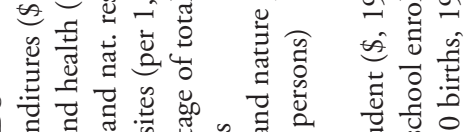

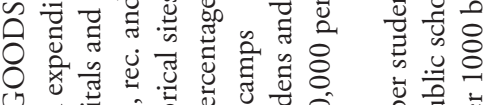

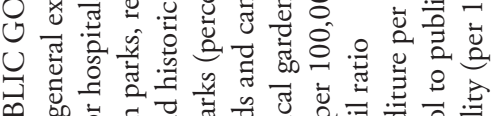
它 总

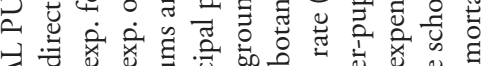

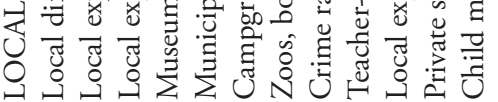

矛

¿

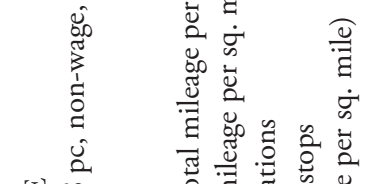

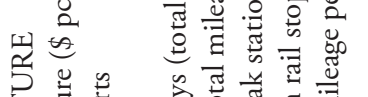

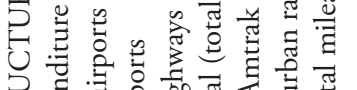

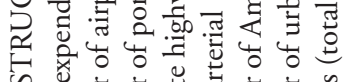
जि $\begin{gathered}0 \\ 0\end{gathered}$

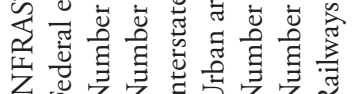

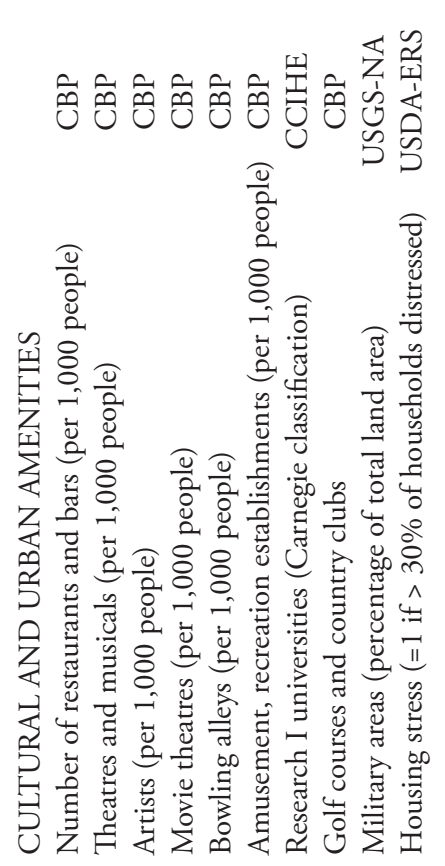

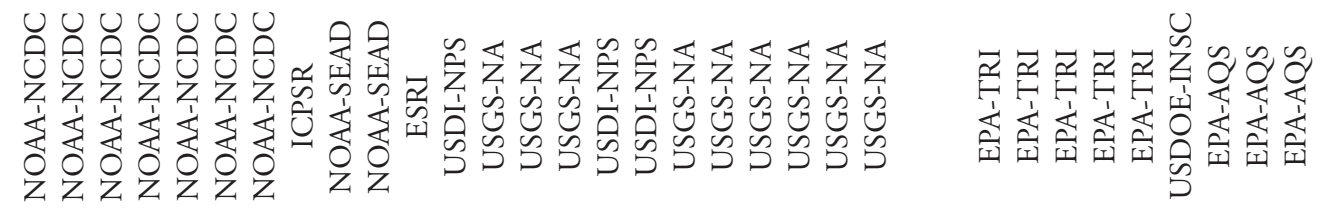

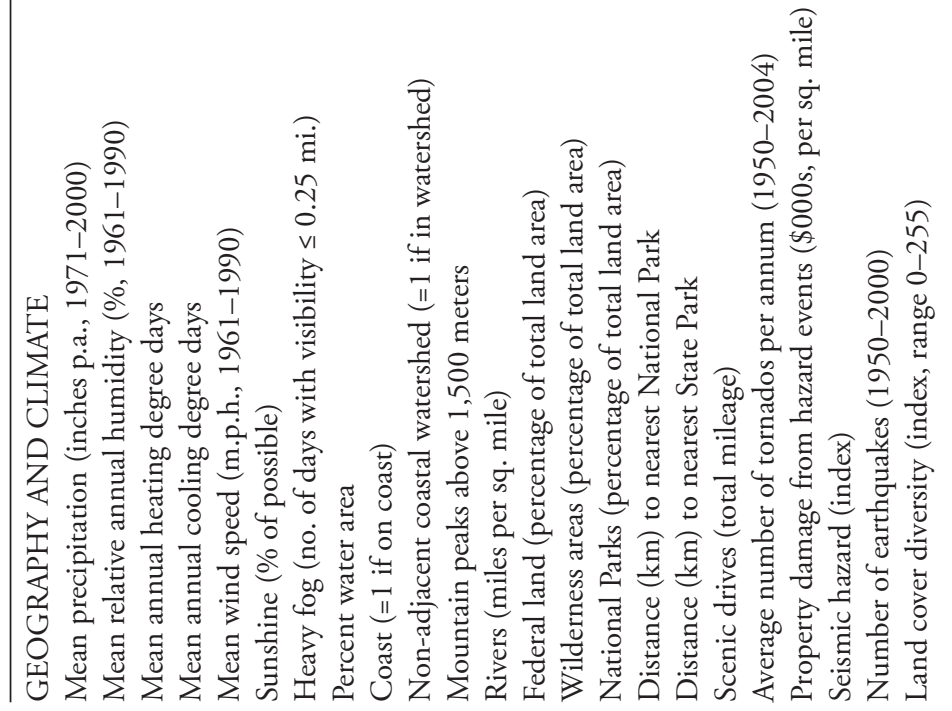

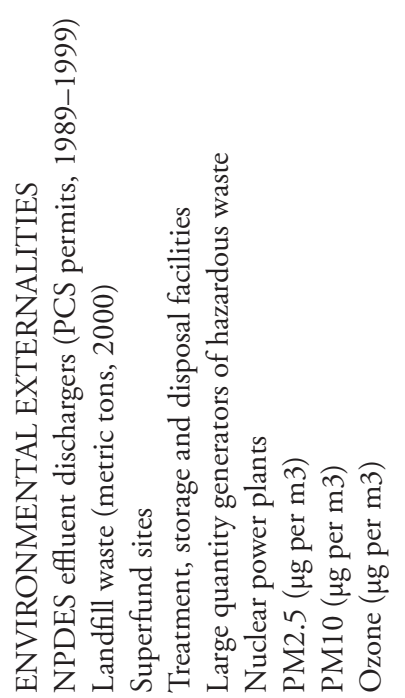




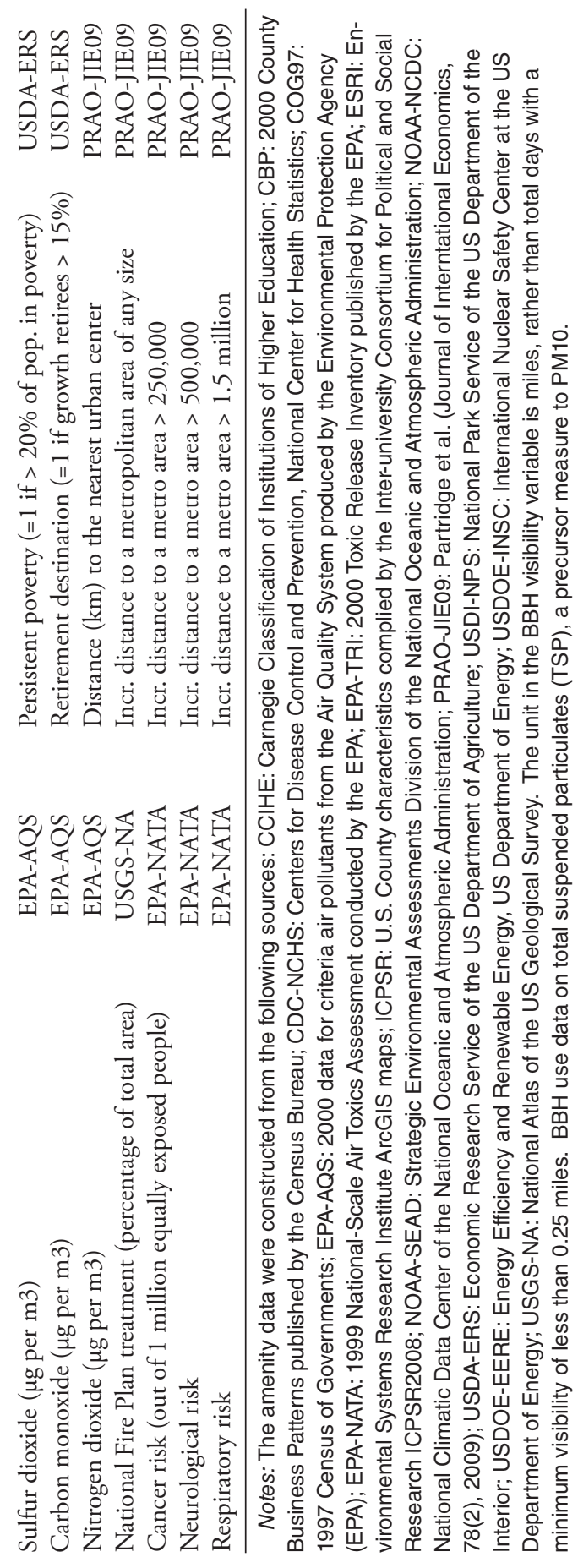


1978. "Superlative Index Numbers and Consistency in Aggregation.” Econometrica 46 (4): 883-900. http://dx.doi.org/10.2307/1909755

Economist Intelligence Unit. 2005. The Economist Intelligence Unit's Quality-of-Life Index. The World in 2005. London, UK.

_.2009. European Green City Index: Assessing the Environmental Impact of Europes Major Cities.

2011. US and Canada Green City Index.

Fisher, Irving. 1922. The Making of Index Numbers: A Study of Their Varieties, Tests and Reliabilities. Cambridge, MA: Riverside Press.

Fleurbaey, Marc. 2009. "Beyond GDP: The Quest for a Measure of Social Welfare." Journal of Economic Literature 47 (4): 1029-1075. http://dx.doi.org/10.1257/jel.47.4.1029

Gabriel, Stuart A., and Stuart S. Rosenthal. 2004. "Quality of the Business Environment Versus Quality of Life: Do Firms and Households Like the Same Cities?” Review of Economics and Statistics 86 (1): 438-444. http://dx.doi.org/10.1162/003465304774201879

Garner, Thesia I., George Janini, William Passero, Laura Paszkiewicz, and Mark Vendemia. 2006. "The CE and the PCE: A Comparison." Monthly Labor Review 129 (9): 20-46.

Glaeser, Edward L., and Matthew E. Kahn. 2010. "The Greenness of Cities: Carbon Dioxide Emissions and Urban Development." Journal of Urban Economics 67 (3): 404-418. http://dx.doi. org/10.1016/j.jue.2009.11.006

Glaeser, Edward L., Jed Kolko, and Albert Saiz. 2001. "Consumer City." Journal of Economic Geography 1 (1): 27-50. http://dx.doi.org/10.1093/jeg/1.1.27

Glaeser, Edward L., and Bryce A. Ward. 2009. "The Causes and Consequences of Land Use Regulation: Evidence from Greater Boston.” Journal of Urban Economics 65 (3): 265-278. http:// dx.doi.org/10.1016/j.jue.2008.06.003

Green, Richard K., Stephen Malpezzi, and Stephen K. Mayo. 2005. "Metropolitan-Specific Estimates of the Price Elasticity of Supply of Housing, and Their Sources." American Economic Review 95 (2): 334-339. http://dx.doi.org/10.1257/000282805774670077

Gyourko, Joseph E., Matthew E. Kahn, and Joseph Tracy. 1999. "Quality of Life and Environmental Comparisons." In Handbook of Regional and Urban Economics: Applied Urban Economics, edited by Paul C. Cheshire and Edwin S. Mills, Vol. 3:1413-1454. Amsterdam: NorthHolland. http://dx.doi.org/10.1016/S1574-0080(99)80006-6

Gyourko, Joseph E., Albert Saiz, and Anita Summers. 2008. "A New Measure of the Local Regulatory Environment for Housing Markets: The Wharton Residential Land Use Regulatory Index." Urban Studies 45 (3): 1-35. http://dx.doi.org/10.1177/0042098007087341

Gyourko, Joseph E., and Joseph Tracy. 1991. "The Structure of Local Public Finance and the Quality of Life." Journal of Political Economy 99 (4): 774-806. http://dx.doi.org/10.1086/261778

Hanley, Nick. 2000. "Macroeconomic Measures of Sustainability." Journal of Economic Surveys 14 (1): 1-30. http://dx.doi.org/10.1111/1467-6419.00102

Hartwick, John M. 1977. "Intergenerational Equity and the Investing of Rents from Exhaustible Resources." American Economic Review 67 (5): 972-974.

Haurin, Donald R. 1980. "The Regional Distribution of Population, Migration, and Climate." Quarterly Journal of Economics 95 (2): 293-308. http://dx.doi.org/10.2307/1885501

Heal, Geoffrey. 2011. "Sustainability and Its Measurement." National Bureau of Economic Research Working Paper, Cambridge, MA.

Hoehn, John P., Mark C. Berger, and Glenn C. Blomquist. 1987. "A Hedonic Model of Interre- 
gional Wages, Rents and Amenity Values.” Journal of Regional Science 27 (4): 605-620. http:// dx.doi.org/10.1111/j.1467-9787.1987.tb01184.x

Jorgenson, Dale W. 2009. "A New Architecture for the U.S. National Accounts." Review of Income and Wealth 55 (1): 1-42. http://dx.doi.org/10.1111/j.1475-4991.2008.00306.x

Jorgenson, Dale W., and J. Steven Landefeld. 2009. "Implementation of a New Architecture for the US National Accounts." American Economic Review 99 (2): 64-68. http://dx.doi.org/10.1257/ aer.99.2.64

Jorgenson, Dale W., J. Steven Landefeld, and William D. Nordhaus, eds. 2006. A New Architecture for the U.S. National Accounts. Cambridge, MA: University of Chicago Press.

Kahn, Matthew E. 2006a. Green Cities: Urban Growth and the Environment. Washington, DC: Brookings Institution Press.

. 2006b. "Environmental Valuation Using Cross-City Hedonic Methods." In Environmental Valuation Interregional and Intraregional Perspectives, edited by John I. Carruthers and Bill Mundy, 27-49. Aldershot, UK: Ashgate Publishing.

2010. Climatopolis: How Our Cities Will Thrive in the Hotter Future. New York: Basic Books.

Klein, Lawrence Robert, and H. Rubin. 1948. "A Constant-Utility Index of the Cost of Living." Review of Economic Studies 15 (2): 84-87. http://dx.doi.org/10.2307/2295996

Kuznets, Simon. 1934. National Income 1929-1932. Washington, DC. 1946. National Income: A Summary of Findings. Cambridge, MA: National Bureau of Economic Research.

Lambiri, Donysia, Bianca Biagi, and Vicente Royuela. 2007. "Quality of Life in the Economic and Urban Economic Literature." Social Indicators Research 84 (1): 1-25. http://dx.doi. org/10.1007/s11205-006-9071-5

Muller, Nicholas Z., Robert Mendelsohn, and William D. Nordhaus. 2011. "Environmental Accounting for Pollution in the United States Economy.” American Economic Review 101 (5): 1649-1675. http://dx.doi.org/10.1257/aer.101.5.1649

National Research Council. 1999. Nature's Numbers: Expanding the National Economic Accounts to Include the Environment, edited by William D. Nordhaus and Edward C. Kokkelenberg. Washington, DC: National Academies Press.

2005. Beyond the Market: Designing Nonmarket Accounts for the United States, edited by Katherine G. Abraham and Christopher Mackie. Washington, DC: National Academies Press.

Neumayer, Eric. 2010. Weak Versus Strong Sustainability: Exploring the Limits of Two Opposing Paradigms. 3rd ed. Cheltenham, UK: Edward Elgar Publishing.

Nordhaus, William D. 2000. "New Directions in National Economic Accounting." American Economic Review 90 (2): 259-263. http://dx.doi.org/10.1257/aer.90.2.259

Nordhaus, William D., and James Tobin. 1972. "Is Growth Obsolete?" In The Measurement of Economic and Social Performance, Studies in Income and Wealth, edited by Milton Moss, Vol.38:509-564. Cambridge, MA: NBER.

Permanyer, Ińaki. 2012. "Uncertainty and Robustness in Composite Indices Rankings." Oxford Economic Papers 64 (1): 57-79. http://dx.doi.org/10.1093/oep/gpr018

Pigou, Arthur Cecil. 1920. The Economics of Welfare. London: Macmillan and Co.

Rappaport, Jordan. 2008. "Consumption Amenities and City Population Density." Regional Science and Urban Economics 38 (3): 533-552. http://dx.doi.org/10.1016/j.regsciurbeco.2008.02.001 2009. “The Increasing Importance of Quality of Life." Journal of Economic Geography 9 (6): 779-804. http://dx.doi.org/10.1093/jeg/lbp009 
Roback, Jennifer. 1982. "Wages, Rents, and the Quality of Life.” Journal of Political Economy 90 (6): 1257-1278. http://dx.doi.org/10.1086/261120

1988. "Wages, Rents, and Amenities: Differences among Workers and Regions." Economic Inquiry 26 (1): 23-41. http://dx.doi.org/10.1111/j.1465-7295.1988.tb01667.x

Rosen, Sherwin. 1979. "Wage-based Indexes of Urban Quality of Life." In Current Issues in Urban Economics, edited by Peter M. Mieszkowski and Mahlon R. Straszheim, 74-104. Baltimore: Johns Hopkins University Press.

Solow, Robert M. 1993. "An Almost Practical Step Toward Sustainability." Resources Policy 19 (3): 162-172. http://dx.doi.org/10.1016/0301-4207(93)90001-4

Suzuki, Hiroaki, Arish Dastur, Sebastian Moffatt, and Nanae Yabuki. 2010. Eco2Cities: Ecological Cities as Economic Cities. Washington, DC: World Bank.

United Nations. 2007. Indicators of Sustainable Development: Guidelines and Methodologies. 3rd ed. New York: United Nations Publications.

Urban China Initiative. 2010. The Urban Sustainability Index: A New Tool for Measuring China's Cities. 